\title{
ANALISIS PENYUSUNAN DAN PELAKSANAAN ANGGARAN OLEH SEKRETARIAT DPRD KABUPATEN JEPARA
}

\author{
Zulkifli Sulistiyono $^{1^{*}}$, Agustina Prativi Nugraheni \\ ${ }^{1,2}$ Universitas Tidar \\ E-mail: ${ }^{1)}$ sulistiyonozulkifli@gmail.com
}

\begin{abstract}
ABSTRAK
Dalam memimpin pemerintahan, aspirasi rakyat sangatlah dibutuhkan untuk melaksanakan pembangunan. Dewan Perwakilan Rakyat Daerah (DPRD) adalah badan pemerintah yang dapat mendengar tentang permasalahan rakyat didalam suatu daerah. Dalam menjalankan pembangunan daerah, DPRD dan Pemerintah memilki peran penting dalam proses penyusunan anggaran. Proses penyusunan anggaran yang efektif dan efisien dapat membuahkan anggaran yang selaras dengan kebutuhan pada periode yang bersangkutan. Penyusunan anggaran ialah sistem yang penting untuk mencapai anggaran yang efektif serta efisien saat dalam pelaksanaannya. Tujuan dari studi ini adalah untuk menganalisis proses penyusunan anggaran dan pelaksanaan anggaran di Sekretariat DPRD Kabupaten Jepara. Metode penelitian ini menggunakan analisis deskriptif melalui observasi dan wawancara. Sekretariat DPRD merupakan satuan kinerja perangkat daerah yang bertanggung jawab kepada Pimpinan DPRD secara operasional dan bertanggung jawab kepada Bupati dalam hal administratif. Dalam proses penyusunan anggaran, Pemerintah dan DPRD sepakat menyusun anggaran berbasis pada kinerja. Anggaran berbasis kinerja memprioritaskan pada output dari pelaksanaan kegiatan yang dicapai berhubungan dengan penggunaan anggaran yang sudah direncanakan.
\end{abstract}

Kata Kunci: Penyusunan, Pelaksanaan, APBD, Berbasis Kinerja.

\section{ABSTRACT}

In leading the government, the aspirations of the people are needed to carry out development. The Regional People's Representative Council (DPRD) is a government body that can hear about the problems of the people in an area. In carrying out regional development, the DPRD and the Government have an important role in the budgeting process. The process of preparing an effective and efficient budget can produce a budget that is in line with the needs in the period concerned. Budgeting is an important system to achieve an effective and efficient budget when in its implementation. The purpose of this study is to analyze the process of budgeting and budget implementation in the Secretariat of the Jepara Regency DPRD. This research method uses descriptive analysis through observation and interviews. The DPRD Secretariat is a regional device performance unit that is responsible to the Dprd Leadership operationally and is responsible to the Regent in administrative matters. In the process of budgeting, the Government and dprd agreed to draw up a budget based on performance. Performance-based budgets prioritize on the output of the implementation of activities achieved related to the use of planned budgets.

Keywords: Drafting, Implementation, APBD, Performance-Based. 


\section{PENDAHULUAN}

Sekretariat DPRD merupakan lembaga pemerintah daerah yang memiliki peran sebagai perangkat pendukung pelayanan administrative bagi DPRD, hal tersebut tertuang dalam UU 23 Tahun 2014 tentang pemerintah daerah yang menafsirkan bahwa dalam menjalankan tugas tersebut Sekretariat DPRD secara operasional bertanggungjawab terhadap pimpinan DPRD sedangkan secara administratif bertanggungjawab terhadap Bupati. Sebagai setuan kinerja perangkat daerah yang membantu DPRD dalam hal operasional, Sekretariat DPRD juga berperan dalam pendampingan keputusan DPRD dalam hal penyusunan APBD dalam suatu daerah. Penyusunan APBD didasarkan berdasarkan penyusunan anggaran berbasis kinerja, hal ini diperkuat dengan terbitnya UU No. 17 Tahun 2003 yang menyebutkan bahwa system penganggaran yang telah berubah dari traditional budget menjadi anggaran berbasis kinerja. UU No. 1 Tahun 2004 tentang Perbendaharaan Negara dan beberapa peraturan pemerintah lainnya yang berfungsi sebagai pilar dalam menjalankan anggaran. Peraturan ini mengubah tata cara struktur penganggaran dari yang semula menggunakan sistem dual budgeting diubah unified budgeting, penganggaran berbasis masukan berubah menjadi penganggaran berbasis kinerja, serta penganggaran jangka menengah. Penyusunan anggaran berbasis kinerja memperhitungkan biaya kerja serta unit dalam pelaksanaan kegiatan, hal ini dikarenakan anggaran berbasis kinerja bukan sekedar berorientasi pada output saja akan tetapi juga pada outcome, benefit dan impact sehingga setiap pekerjaan harus menetapkan tujuan yang jelas terlebih dahulu.

Pengalokasian dana yang efektif memiliki arti bahwa dalam setiap pengeluaran pemerintah menuju pada sasaran dan tujuan strategis yang telah dimuat dalam dokumen perencanaan strategis. Sedangkan, pengalokasian dana yang efisien memiliki arti bahwa dalam setiap pengeluaran dapat mencapai sasaran dan tujuan strategis dengan penggunaan sumber daya yang minimal dengan kualitas optimal. Pengalokasian pengeluaran yang efektif dan efisien dapat diterapkan melalui performance-based budgeting dalam penyusunan anggaran pemerintah. Performance-based budgeting bertujuan untuk meningkatkan efektifitas dan efisiensi pengeluaran belanja dengan cara pencapaian penggunaan informasi kinerja secara sistematis dari setiap organisasi sektor publik (Robinson dan Last (2019)).

\section{LANDASAN TEORI}

\subsection{Pengertian dan Fungsi Anggaran}

Anggaran berasal dari kata budget (Inggris), yang berarti sebuah tas kecil sebelumnya dari kata bougette (Perancis). Menurut Indra Bastian, definisi anggaran (budget) adalah rencana operasi keuangan, yang mencakup estimasi pengeluaran yang diusulkan, dan sumber pendapatan yang diharapkan untuk membiayainya dalam periode waktu tertentu, berdasarkan The National Committee on Governmental Accounting (NCGA) yang sekarang telah berganti menjadi Governmental Accounting Standards Board (GASB). Anggaran negara adalah rencana keuangan pemerintah untuk periode satu tahun yang akan datang yang digunakan untuk membiayai operasional kegiatan bernegara dalam segala bidang.

Anggaran mempunyai tiga tujuan utama yang saling terkait, yaitu stabilitas fiskal makro, alokasi sumber daya yang sesuai prioritas, dan pemanfaatan anggaran secara efektif dan efisien. Instrumen kebijakan ekonomi anggaran berfungsi untuk mewujudkan pertumbuhan ekonomi, stabilitas ekonomi, dan pemerataan pendapatan, sebagai instrumen 
kebijakan ekonomi anggaran. Selain itu anggaran negara juga berfungsi sebagai media perencanaan dan pengawasan aktivitas pemerintahan.

Anggaran mencerminkan adanya unsur keterbatasan dalam arti kata asalnya. Karena keterbatasan sumber daya yang dimiliki pemerintah, anggaran perlu disusun secara efektif dan efisien. Disebabkan oleh jumlah dana yang terbatas, alokasi diperlukan sesuai dengan jangka waktu yang telah ditentukan. Hariadi, Yanuar, and Icuk (2010:7) mendefinisikan anggaran sebagai perkiraan apa yang akan terjadi selama periode waktu tertentu yang ditentukan berdasarkan keuangan suatu negara. Mardiasmo (2013:63) menyebutkan terdapat beberapa jenis fungsi anggaran yang berbeda dalam manajemen sektor publik.

1. Anggaran sebagai alat perencanaan

2. Anggaran sebagai alat pengendalian

3. Anggaran sebagai alat kebijakan

4. Anggaran sebagai alat politik

5. Anggaran sebagai alat koordinasi dan komunikasi

6. Anggaran sebagai alat penilaian kinerja

7. Anggaran sebagai alat motivasi.

\subsection{Anggaran Berbasis Kinerja}

Penyusunan APBD didasarkan pada anggaran yang berbasis kinerja atau prestasi kerja. Anggaran berbasis kinerja adalah pendekatan penganggaran yang mengutamakan hasil kegiatan yang akan atau telah dicapai sesuai dengan rencana anggaran yang telah ditentukan serta kuantitas dan kualitas yang terukur. Setiap dana yang dikeluarkan untuk menjalankan program harus terukur secara jelas indicator kinerja yang di representasikan sehingga dapat memenuhi tolok ukur sasaran. Selain itu dalam menyusun APBD diorientasikan pada penyusunan anggaran secara terpadu (unified budget), dimana semua belanja pemerintah didasarkan pada prinsip efisiensi alokasi dana. Penyusunan APBD secara terpadu selaras dengan penyusunan anggaran berbasis kinerja.

\subsection{Penyusunan Anggaran}

Langkah-langkah yang harus dilakukan oleh pemerintah daerah dalam menyusun APBD, adalah :

1. Penyusunan Kebijakan Umum APBD (KUA)

Tim Anggaran Pemerintah Daerah (TAPD) bersama Panitia Anggaran DPRD menyampaikan rancangan KUA kepada DPRD untuk dibahas oleh Tim Anggaran Pemerintah Daerah (TAPD) bersama Panitia Anggaran DPRD dalam pembicaraan pendahuluan RAPBD tahun berikutnya. Rancangan KUA berisi tentang program menurut usulan pemerintah, organisasi, sasaran dan target kinerja serta pagu anggaran indikatif

2. Penyusunan Prioritas dan Plafon Anggaran Sementara (PPAS)

Kepala Daerah menyampaikan rancangan PPAS kepada DPRD untuk dibahas oleh TAPD bersama Panitia Anggaran DPRD, berdasarkan KUA yang telah disepakati. Rancangan PPAS berisi tentang urutan prioritas program dan kegiatan, sasaran, dan kinerja target masing-masing program. 
3. Penyusunan dan Penyampaian Surat Edaran Kepala Daerah tentang Pedoman Penyusunan RKA-SKPD

Penyusunan RKA-SKPD dalam Nota Kesepakatan PPA antara Kepala Daerah dan Pimpinan DPRD didasarkan pada program dan kegiatan serta pagu anggaran definitif yang tercantum dalam Nota Kesepakatan PPA antara Kepala Daerah dan Pimpinan DPRD. Substansi surat edaran Kepala Daerah tersebut meliputi:

a. PPA yang disalurkan untuk kegiatan SKPD, terhadap rencana pendapatan dan pembiayaan

b. Penyelarasan program serta kegiatan SKPD dengan kinerja SKPD berkenaan yang ditetapkan.

c. Batas waktu RKA-SKPD menyampaian kepada PPKD.

d. Hal yang perlu dijadikan perhatian khusus dari SKPD berkaitan dengan efektifitas, efisiensi, transparansi dan akuntabilitas penyusunan anggaran dalam hal tercapainya prestasi kerja

e. Dokumen yang dijadikan lampiran terdiri dari KUA, PPA, kode rekening APBD, format RKA-SKPD, Analisa standar belanja dan standar satuan harga.

4. Penyusunan Rancangan Peraturan Daerah tentang APBD dan Rancangan Peraturan Kepala Daerah tentang Penjabaran APBD.

Rancangan APBD yang dituangkan dalam masing-masing Rencana Kegiatan dan Anggaran Satuan Kerja Perangkat Daerah merupakan agregasi dari usulan-usulan yang telah disusun dan diajukan oleh organisasi pemerintah daerah maupun Satuan Kerja Perangkat (RKA-SKPD). Usulan tersebut dimaksud dapat menjadi jumlah anggaran pendapatan, belanja setiap program dan kegiatan, serta pembiayaan yang hendak dilaksanakan dalam tahun anggaran selanjutnya.

5. Penyampaian dan Pembahasan Rancangan Peraturan Daerah tentang APBD dan Peraturan Kepala Daerah tentang Penjabaran APBD.

\section{METODE PENELITIAN}

\section{Jenis Penelitian}

Jenis penelitian kualitatif merupakan tipe penelitian yang memiliki sifat deskriptif, penelitian ini lebih mengutamakan analisis dalam pembahasannya. Karena lebih mengutamakan analisis dalam pembahasannya, peneliti menggali data dari observasi dan wawancara selama magang/praktik kerja lapangan saat di Sekretariat DPRD Kabupaten Jepara. Selain itu peneliti juga ingin menggambarkan tentang cara penyusunan dan pelaksanaan anggaran yang dilakukan oleh Sekretariat DPRD Kabupaten Jepara.

\section{Tempat dan Waktu Penelitian}

Penelitian ini dilaksanakan pada Kantor Sekretariat DPRD Kabupaten Jepara, dan waktu penelitian dilakukan pada tanggal 5 Agustus hingga 6 September 2021. 


\section{Teknik Pengumpulan Data}

Teknik pengumpulan data dilakukan dengan cara observasi dan studi dokumentasi selama penulis melaksanakan magang/praktik kerja lapangan di Sekretariat DPRD Kabupaten Jepara. Observasi (pengamatan) dilakukan penulis dengan cara melihat laporan Dokumen Pelaksanaan Anggaran Rekapitulasi SKPD Sekretariat DPRD Penyesuaian Hasil Evaluasi APBD 2021. Kemudian melakukan wawancara terhadap karyawan di Sekretrariat DPRD Kabupaten Jepara terhadap pelaksanaan anggaran yang telah direncanakan pada tahun 2021.

\section{Tujuan Penelitian dan Manfaat}

Penelitian ini dilaksanakan dengan tujuan untuk mengidentifikasi tentang cara penyusunan dan pelaksanaan anggaran pada Sekretariat DPRD Kabupaten Jepara.

Manfaat penelitian dalam hal ini dapat diklasifikasikan sebagai berikut:

1. Manfaat Teoretis

Manfaat teoretis merupakan manfaat yang memiliki lingkup tentang pengembangan ilmu, penelitian ini dapat digunakan sebagai pengembangan ilmu mengenai penyusunan dan pelaksanaan anggaran pada Sekretariat DPRD Kabupaten Jepara.

2. Manfaat Praktis

Manfaat praktis adalah manfaat yang dapat diambil oleh penulis dan pembaca dari penulisan artikel ini. Artikel ini diharapkan dapat menambah kontribusi terhadap pembaca mengenai pentingnya penyusunan dan pelaksanaan anggaran oleh Sekretariat DPRD Kabupaten Jepara.

\section{HASIL PENELITIAN DAN PEMBAHASAN}

\subsection{Susunan organisasi satuan kinerja perangkat daerah Sekretariat DPRD} Kabupaten Jepara

Berdasarkan peraturan pemerintah daerah Kabupaten Jepara No. 16 Tahun 2010 berkaitan dengan organisasi dan tata kerja Sekretariat Daerah serta Sekretariat DPRD Kabupaten Jepara menyebutkan bahwa sesuai kedudukannya Sekretariat DPRD merupakan satuan kinerja perangkat daerah yang berperan memberikan pelayanan terhadap aktifitas DPRD, dipimpin oleh Sekretaris yang bertanggung jawab kepada pimpinan DPRD dan secara administratif dibina oleh Sekretariat Daerah. Berikut adalah susunan organisasi, beserta tugas pokok dan fungsi :

- Susunan Organisasi

1) Sekretaris DPRD

2) Kabag Persidangan dan Perundang-undangan

a. Kasubbag Perundang-undangan, Humas dan Publikasi.

b. Kasubag Persidangan, Risalah, dan Protokol.

3) Kabag Pengganggaran dan Pengawasan.

a. Kasubbag Penganggaran

b. Kasubbag Pengawasan, Kerjasama, dan Aspirasi.

4) Kabag Umum

a. Kasubbag TU/Kepegawaian 
b. Kasubbag Rumah Tangga dan Perlengkapan

5) Kabag Program dan Keuangan

a. Kasubbag Perencanaan dan Penganggaran

b. Kasubbag Verifikasi, Akuntansi, dan Pelaporan.

\subsection{Pelaksanaan Anggaran}

\begin{tabular}{|c|c|c|c|c|}
\hline \multicolumn{3}{|c|}{ Kode Rekening } & Uraian & Jumlah (Rp) \\
\hline 5 & & & BELANJA & \\
\hline 5 & 1 & & Belanja Operasi & Rp60.890.133.000 \\
\hline 5 & 1 & 1 & Belanja Pegawai & Rp30.390.300.000 \\
\hline 5 & 1 & 2 & Belanja Barang dan Jasa & Rp30.499.833.000 \\
\hline 5 & 2 & & Belanja Modal & Rp537.700.000 \\
\hline 5 & 2 & 2 & Belanja Modal Peralatan dan Mesin & Rp537.700.000 \\
\hline & & & Jumlah Belanja & $\operatorname{Rp} 61.427 .833 .000$ \\
\hline
\end{tabular}

Gambar 1:

Pelaksanaan Anggaran Belanja Daerah Sekretariat DPRD

Sumber: Ringkasan DPA APBD Satuan Kinerja Perangkat Daerah 2021

Penyusunan Dokumen Pelaksanaan Anggaran Satuan Kerja Perangkat Daerah (DPA-SKPD) dan anggaran kas oleh SKPD yang dilanjutkan dengan tahapan pelaksanaan APBD, penatausahaan dan proses akuntansi keuangan daerah. Pasal 122 Permendagri nomor 13 tahun 2006 terkait pelaksanaan APBD sebagai berikut:

1. Penerimaan dan pengeluaran daerah dikelola oleh APBD dalam rangka pelaksanaan urusan pemerintahan daerah.

2. Setiap SKPD memiliki kewajiban untuk melakukan pemungutan dan penerimaan berdasarkan peraturan perundang-undangan

3. Penerimaan SKPD akan langsung digunakan untuk membiayai pengeluaran, sesuai dengan peraturan perundang-undangan.

4. Uang dan cek yang diterima oleh SKPD wajib disetorkan ke rekening kas umum daerah paling lama satu hari kerja.

5. Jumlah total belanja dalam APBD adalah estimasi tertinggi untuk pengeluaran belanja

6. Pengeluaran tidak dibebankan pada anggaran belanja jika pengeluaran ini tidak cukup tersedia dalam APBD. Pengeluaran ini dapat dilakukan jika dalam keadaan darurat, yang diusulkan melalui rancangan perubahan APBD atau disampaikan dalam laporan realisasi anggaran.

7. Setiap SKPD tidak boleh melakukan pengeluaran melebihi beban anggaran daerah yang telah ditetapkan APBD

8. Belanja daerah berpedoman hemat, efektif, efisien dan sesuai peraturan perundangundangan

DPA-SKPD (Dokumen Pelaksanaan Anggaran SKPD) merupakan dokumen yang berisi pendapatan, belanja, dan pembiayaan yang digunakan oleh pengguna 
anggaran/pengguna barang sebagai dasar pelaksanaan anggaran. Pelaksanaan APBD terbagi menjadi tiga pembahasan, yaitu pendapatan, belanja, dan pembiayaan.

A. Pelaksanaan Anggaran Pendapatan Daerah.

Pelaksanaan Anggaran Pendapatan Daerah merupakan kegiatan pemungutan pendapatan daerah. Pendapatan daerah merupakan hak pemerintah daerah yang diakui sebagai penambah ekuitas dana lancar pada tahun bersangkutan.

B. Pelaksanaan Anggaran Belanja Daerah.

Pelaksanaan anggaran belanja daerah merupakan penggunaan kas yang digunakan untuk mengurangi ekuitas dana lancar pada tahun bersangkutan, serta pembayarannya tidak diperbolehkan kembali kepada pemerintah.

C. Pelaksanaan Anggaran Pembiayaan Daerah.

Pelaksanaan anggaran pembiayaan daerah ialah semua penerimaan yang harus dibayar kembali dan/ atau pengeluaran yang akan diterima kembali, baik pada tahun anggaran bersangkutan maupun tahun anggaran lain, hal ini digunakan untuk menutup defisit serta memanfaatkan surplus anggaran.

\section{KESIMPULAN}

Anggaran pendapatan dan belanja daerah (APBD) merupakan anggaran yang digunakan pemerintah untuk menjalankan pemerintahan daerah dalam kurun waktu satu tahun berlangsung. Anggaran tersebut dibuat oleh pemerintah dan dibahas dengan DPRD. Sekretariat DPRD merupakan lembaga pemerintah yang secara operasional bertanggung jawab kepada Pimpinan DPRD serta secara administratif bertanggung jawab kepada Bupati. Dalam proses penyusunan anggaran, APBD dibuat sebelum tahun anggaran berlangsung atau sering disebut Rancangan Anggaran Pendapatan dan Belanja Daerah (RAPBD). Setelah RAPBD disetujui oleh Pemerintah dan DPRD maka akan menjadi APBD dalam tahun yang bersangkutan dan digunakan untuk periode waktu satu tahun. Selama mengelola APBD, lembaga pemerintah yang menggunakan APBD diharuskan untuk menggunakan anggaran berbasis kinerja agar output yang dihasilkan sesuai dengan rencana yang diharapkan sebelumnya. Selain itu juga hal ini dapat digunakan untuk menuju pada prinsip hemat, efektif dan efisien. Tujuan penelitian ini yaitu untuk mengetahui proses penyusunan serta pelaksanaan anggaran yang dilakukan oleh Sekretariat DPRD Kabupaten Jepara. Dalam membuat artikel ini, penulis menggunakan data sekunder, seperti halnya; buku, artikel ilmiah, maupun laporan keuangan.

Saran dari penulis mengenai artikel ini adalah kurangnya data mengenai kegiatan pelaksanaan anggaran yang dilakukan oleh Sekretariat DPRD Kabupaten Jepara. Hal ini karena banyaknya kegiatan yang dilaksanakan untuk tahun anggaran berlangsung sehingga kegiatan-kegiatan yang dilakukan selama tahun berlangsung tidak dapat dituliskan satu persatu. 


\section{DAFTAR PUSTAKA}

Avitta Kurnia Dewi, R. W. (2021). Tugas Dan Wewenang Dprd Dalam Pelaksanaan Fungsi Anggaran Terhadap Anggaran Pendapatan Dan Belanja Daerah (Apbd) Provinsi Jawa Tengah. Jurnal Edukasi, 5-10.

DPA Rekapitulasi SKPD Sekretariat DPRD Kabupaten Jepara. (2021). Jepara: Pemerintah Kabupaten Jepara.

Haryanto, S. (2008). Perencanaan Dan Penganggaran Daerah Pendekatan Kinerja. Semarang: Badan Penerbit UNDIP.

Haryanto, S. A. (2007). Akuntansi Sektor Publik. Semarang: Badan Penerbit Universitas Diponegoro.

Neni Rahmawati, A. M. (t.thn.). Implementasi Standar Akuntansi Pemerintahan Berbasis Akrual di Sekretariat DPRD Kabupaten Malang Berdasar Peraturan Pemerintah Nomor 71 Tahun 2010. 2018.

Ningsih, K. (2020). Pelaksanaan Perencanaan, Evaluasi, Dan Pelaporan Pada Sekretariat Dprd Kabupaten Banjarnegara. Jurnal Paradigma Multi Disipliner.

Novi Ardhia Cahyani, S. N. (2021). Penerapan Koreksi Kesalahan Pada Laporan Keuangan Unaudited Di Sekretariat DPRD Provinsi Jawa Tengah. Jurnal Edukasi, 11-18.

Rinni Oike Rorong, L. K. (2007). Analisis Sistem Penyusunan Anggaran Pemerintah Kota Manado (Studi Kasus Pada Sekretariat DPRD Kota Manado). Jurnal EMBA, 23312340.

Sekretariat DPRD Kabupaten Jepara. (t.thn.). Diambil kembali dari setwan.jepara.go.id.: https://setwan.jepara.go.id/ 